\title{
KEWENANGAN PEGADAIAN DALAM MENERBITKAN SERTIFIKAT BATU MULIA DI INDONESIA
}

\author{
Alif Arhanda Putra \\ Fakultas Hukum, Universitas Borneo Tarakan \\ Tarakan, Kalimantan Utara, Indonesia \\ alifarhanda@gmail.com
}

\begin{abstract}
Authority of Pegadaian in Issuance of the Certificates of Precious Stones in Indonesia.

This research aimed to determine the institution authorized to issue the certificate of the precious stones in Indonesia. This study used the empirical research type to look at the enforcement of the law from the non-legal aspect. The collected data - both primary and secondary data - were analyzed qualitatively. Then, they were described in order to answer the problems of this research.

The research results revealed that The authority to issue certificates for the precious stones in Indonesia was given to the authorized and powerful institutes in order to issue certificates for the precious stones in Indonesia, such as the Pawnshop and order private institutes as the actors in the commerce industry of precious stones in Indonesia.
\end{abstract}

Keywords: Authority, The Pawnshop, Certificates of Precious Stones.

\section{Pendahuluan}

Batu mulia adalah segala jenis batuan, mineral, dan bahan alam lainnya termasuk beberapa jenis bahan organik, yang setelah diproses dengan sentuhan teknologi, memiliki keindahan dan ketahanan yang mencukupi untuk dijadikan sebagai batu permata. Seperti halnya istilah diamond yang mencakup intan sebagai bahan mentah dan berlian setelah intan itu diproses menjadi batu permata, maka pengertian batu mulia yang bahasa Inggrisnya gemstone mencakup segala bahan mentah yang dapat diproses menjadi batu permata.

Perkembangan batu mulia Indonesia sejak setahun terakhir ini menunjukkan perkembangan yang sangat menggembirakan menyusul publikasi dan promosi yang dilancarkan secara luas dan terus menerus oleh Majalah Gemstone yang terbit sebulan sekali sejak Oktober 2013. Beragam jenis batu mulia, baik temuan lama ataupun temuan baru, ditampilkan di majalah berwarna tersebut berikut tokoh-tokoh terkemuka batu mulia Indonesia, seperti misalnya krisopras Ohen dan pancawarna Edong dari Garut (Jawa Barat), opal dari Banten, jasper hijau dari Klawing Purbalingga (Jawa Tengah), akik Kladen dari Pacitan (Jawa Timur), kalsedon biru dari Baturaja (Sumatra Selatan), 
idokras/batu Sungai Dareh dari Solok Selatan (Sumatra Barat), kuarsa krisokola/batu Bacan dari Pulau Kasiruta (Maluku Utara).

Salah satu bidang usaha yang terdapat di Indonesia adalah Perum Pegadaian, yang merupakan lembaga pembiayaan bukan bank yang melakukan jasa pemberian pinjaman uang/kredit kepada masyarakat dengan cara menguasai benda/barang yang digadaikan oleh para nasabah dan setelah dilakukan penaksiran harga terhadap barang/benda tersebut maka para nasabah dapat langsung menerima pinjaman uang dari barang/benda yang digadaikan tersebut. Penyaluran uang pinjaman kepada masyarakat tersebut didasarkan pada hukum gadai. Dan apabila pada waktu yang telah ditetapkan (jatuh tempo) pinjaman yang diperoleh tidak dikembalikan, maka barang jaminan tersebut dapat dijual lelang guna menutup pengembalian pinjaman dan jika masih ada nilai sisanya maka akan dikembalikan kepada peminjam.

Salah satu bidang usaha yang terdapat di Indonesia adalah Perum Pegadaian, yang merupakan lembaga pembiayaan bukan bank yang melakukan jasa pemberian pinjaman uang/kredit kepada masyarakat dengan cara menguasai benda/barang yang digadaikan oleh para nasabah dan setelah dilakukan penaksiran harga terhadap barang/benda tersebut maka para nasabah dapat langsung menerima pinjaman uang dari barang/benda yang digadaikan tersebut. Penyaluran uang pinjaman kepada masyarakat tersebut didasarkan pada hukum gadai. Dan apabila pada waktu yang telah ditetapkan (jatuh tempo) pinjaman yang diperoleh tidak dikembalikan, maka barang jaminan tersebut dapat dijual lelang guna menutup pengembalian pinjaman dan jika masih ada nilai sisanya maka akan dikembalikan kepada peminjam.

\section{Rumusan Masalah}

Adapun rumusan masalah dalam penelitian ini adalah kewenangan Pegadaian dalam menerbitkan sertifikat batu mulai di Indonesia.

\section{Metode Penelitian}

\section{Jenis Penelitian}

Tipe penelitian yang digunakan dalam penelitian adalah tipe penelitian hukum empiris yakni metode penelitian hukum yang melihat keberlakuan hukum dari segi nonhukum (Nurbani, 2013).

\section{Lokasi Penelitian}


Lokasi penelitian berlangsung di Kantor Pusat PT. Pegadaian (Persero) (Gemologi Laboratorium Perum Pegadaian), ACC Gemological Laboratory, Stonestory Indonesia dan Gem Research International Lab (GRI).

\section{Populasi dan Sampel}

Populasi adalah PT. Pegadaian (Persero) (Gemologi Laboratorium Perum Pegadaian), ACC Gemological Laboratory, Stonestory Indonesia sebagai objek utama penelitian, gemologist G-Lab P.T. Pegadaian, gemologist ACC Gemological Lab. dan gemologist Stonestory Indonesia.

\section{Pengumpulan Data}

Pengumpulan data dilakukan dengan cara wawancara, yaitu cara pengumpulan data dengan mendatangi responden dan mengadakan tanya jawab. Selanjutnya, dokumentasi, yaitu dengan mengkaji berbagai literatur, membaca dan menelaah data yang ada kaitannya dengan permasalahan yang dibahas atau dikaji dalam penelitian ini serta mendukung keberadaan sertifikat batu mulia di Indonesia.

\section{Analisis Data}

Seluruh data yang diperoleh dalam penelitian, dianalisis dengan menggunakan analisis kualitatif.Setelah itu dideskripsikan dengan menelaah permasalahan yang ada, menggambarkan, menguraikan hingga menjelaskan permasalahan-permasalahan yang berkaitan dengan penelitian.

\section{PEMBAHASAN}

Penelitian ini menunjukkan bahwa sertifikat adalah surat keterangan atau pernyataan tertulis atau tercetak dari orang yang berwenang yang dapat digunakan sebagai bukti pemilikan atau suatu kejadian; suatu akta yang sengaja dibuat untuk tanda bukti tentang adanya suatu peristiwa hukum tertentu. ${ }^{50}$

Black's Law Dictionary, certificate is a document in which a fact is formally attested. Dan secara khusus disebutkan pula certificate of registration is copyright Office document approving a copyright application and stating the approved work's registration date and

\footnotetext{
${ }^{50}$ M. Marwan dan Jimmy P. 2009. Kamus Hukum; Dictionary Of Law Complete Edition. Reality Publisher: Surabaya. HIm. 563
} 
copyright number (cases : Copyright and Intellectual Property). .51

Dasar kekuatan hukum sebuah sertifikat yang diterbitkan oleh pegadaian dan lembaga swasta ialah peraturan yang mengatur tentang kewenangan untuk menerbitkan sertifikat batu mulia tersebut. Hal ini dimulai dengan adanya kewenangan yang diatur dalam sebuah peraturan untuk menerbitkan sebuah sertifikat. Hal ini telah dicontohkan oleh Pegadaian sebagai salah satu lembaga yang menerbitkan sertifkat batu mulia di Indonesia. Sebelum menerbitkan sertifikat batu mulia, Pegadaian telah memili peraturan pemerintah No. 51 Tahun 2011 yang salah satu pasalnya mengatur tentang kewenangan Pegadaian menerbitkan sertifkat.

Berdasarkan hal tersebut sehingga Pegadaian membuat standar operasional prosedur dalam menerbitkan sertifikat batu mulia yang dimulai dengan pemeriksaan batu mulia hingga penerbitan sertifikat batu mulia dengan durasi waktu lebih kurang 4060 menit. Sertifikat yang diterbitkan oleh Pegadaian ialah sertifikat yang berdasar pada sebuah peraturan pemerintah. Sedangkan sertifikat yang diterbitkan oleh lembaga swasta ialah sertifikat yang berdasarkan pada pengetahuan gemologist yang bersertifikatkan institute gemology luar negeri. Pengetahuan yang dimiliki gemologist diyakini memiliki pengaruh terhadap penerbitan sertifikat serta keberadaan lembaga swasta tersebut diakui oleh masyarakat sebagai pelaku dalam industry batu mulia di Indonesia.

Sertifikat batu mulia yang diterbitkan Pegadaian dan lembaga swasta memiliki kekuatan hukum sebagai legitimasi atau bukti atas keaslian batu mulia yang dimiliki sehingga dapat memberikan dampak positif dan meningkatkan hargabatu mulia tersebut. Namun, kekurangan sertifikat tersebut ialah tak memiliki atau mencantumkan nama pemilik batu mulia tersebut sehingga masih dimungkinkannya pemalsuan kepemilikan sertifikat batu mulia beserta sertifikatnya.

Hal tersebut juga ditambahkan dan telah sesuai dengan konsep yang menyatakan bahwa kepastian hukum mengandung 2 (dua) pengertian, yaitu pertama, adanya aturan yang bersifat umum membuat individu mengetahui perbuatan apa yang boleh atau tidak boleh dilakukan dan kedua, berupa keamanan hukum bagi individu dari kesewenangan pemerintah karena dengan adanya aturan yang bersifat umum itu individu dapat mengetahui apa saja yang boleh dibebankan atau dilakukan oleh negara terhadap

\footnotetext{
${ }^{51}$ Bryan A. Garner. 2004. Black's Law Dictionary (Eighth Edition). Thomson West Group: United State Of America. HIm. 241
} 
individu. Kepastian hukum bukan hanya berupa pasal-pasal dalam undang-undang, melainkan juga adanya konsistensi dalam putusan hakim antara putusan hakim yang satu dengan putusan hakim lainnya untuk kasus serupa yang telah diputuskan.

Negara berperan dalam setiap perbuatan hukum yang dilakukan oleh masyarakat termasuk dalam penerbitan sertifikat batu mulia, negara dalam hal ini diwakili oleh pemerintah diharapkan berperan sebagai badan legitimasi yang akan menerbitkan sertifikat batu mulia di Indonesia. Salah satu sumber menyebutkan bahwa sertifikat adalah surat keterangan atau pernyataan tertulis atau tercetak dari orang yang berwenang yang dapat digunakan sebagai bukti pemilikan atau suatu kejadian; suatu akta yang sengaja dibuat untuk tanda bukti tentang adanya suatu peristiwa hukum tertentu (Hukum Dagang). ${ }^{52}$ Serta Kamus Besar Bahasa Indonesia Edisi Ketiga menjelaskan ser.ti.kat /sertifikat/ $n$ tanda atau ${ }^{53}$ surat keterangan (pernyataan) tertulis atau tercetak dari orang yang berwenang yang dapat digunakan sebagai bukti pemilikan atau suatu kejadian - tanah.

Secara konseptual, istilah wewenang atau kewenangan sering disejajarkan dengan istilah Belanda yaitu bevoegheid yang berarti wewenang atau berkuasa. Wewenang merupakan bagian yang sangat penting dalam hukum administrasi negara karena pemerintahan baru dapat menjalankan fungsinya atas dasar wewenang yang diperolehnya. Keabsahan tindakan pemerintah diukur berdasarkan wewenang yang diatur dalam peraturan perundang-undangan. Wewenang adalah kemampuan bertindak yang diberikan oleh undang-undang untuk melakukan hubungan dan perbuatan hukum. ${ }^{54}$

Konsep wewenang dapat juga dianalisis melalui telaah sumber wewenang dan konsep pembenaran tindakan kekuasaan pemerintahan. Teori sumber wewenang tersebut meliputi atribusi, delegasi dan mandat.55 Menurut Philipus M. Hadjon, wewenang (bevoegheid) dideskripsikan sebagai kekuasaan hukum (rechtmascht). Jadi, konsep hukum publik berkaitan dengan kekuasaan. ${ }^{56}$

\footnotetext{
52 M. Marwan dan Jimmy P. 2009. Kamus Hukum; Dictionary Of Law Complete Edition. Reality Publisher: Surabaya. HIm. 563

53 Tim Penyusun Kamus Pusat Bahasa. 2002. Kamus Besar Bahasa Indonesia (KBBI) Edisi Ketiga. Balai Pustaka: Jakarta. HIm. 1052

54 Indroharto, 1994, Asas-Asas Umum Pemerintahan yang Baik, Bandung: Citra Aditya Bakti. HIm. 51

55 I Dewa Gede Atmadja. 1996. Penafsiran Konstitusi dalam Rangka Sosialisasi Hukum:Sisi Pelaksanaan UUD 1945 Secara Murni dan Konsekuen. Universitas Udayana : Fakultas Hukum. HIm. 3

${ }^{56}$ Philipus M. Hadjon. 2010. Hukum Administrasi dan Good Governance. Jakarta : Universitas Trisakti. HIm. 25
} 
Wewenang terdiri atas sekurang-kurangnya tiga komponen, yaitu pengaruh, dasar hukum dan konformitas hukum. Komponen pengaruh lah bahwa penggunaan wewenang dimaksudkan untuk mengendalikan perilaku subyek hukum. Komponen dasar hukum berarti wewenang itu harus ditunjuk dasar hukumnya dan komponen konformitas hukum mengandung adanya standar wewenang.

\section{PENUTUP}

\section{Kesimpulan}

Kewenangan untuk menerbitkan sertifikat batu mulia di Indonesia ialah lembaga yang berwenang dan berkepentingan untuk menerbitkan sertifikat batu mulia di Indonesia seperti : Pegadaian dan lembaga swasta sebagai pelaku dalam industri perdagangan batu mulia di Indonesia. Kekuatan hukum sertifikat batu mulia yang diterbitkan oleh Pegadaian maupun lembaga swasta memberikan legitimasi sebagai produk hukum atas keaslian batu mulia tersebut. Meningkatkan nilai atas batu mulia tersebut dalam industri batu mulia di Indonesia. Serta tergolong dalam benda bergerak yang belum bisa dijaminkan.

\section{Saran}

Perlu adanya kewenangan yang jelas untuk lembaga penerbit sertifikat batu mulia di Indonesia untuk menghindari konflik kewenangan dalam menerbitkan sertifikat batu mulia di Indonesia.

\section{DAFTAR PUSTAKA}

Bryan A. Garner. 2004. Black's Law Dictionary (Eighth Edition). Thomson West Group: United State Of America.

I Dewa Gede Atmadja. 1996. Penafsiran Konstitusi dalam Rangka Sosialisasi Hukum:Sisi Pelaksanaan UUD 1945 Secara Murni dan Konsekuen. Universitas Udayana: Fakultas Hukum.

Indroharto, 1994, Asas-Asas Umum Pemerintahan yang Baik, Bandung: Citra Aditya Bakti. M. Marwan dan Jimmy P. 2009. Kamus Hukum; Dictionary Of Law Complete Edition. Reality Publisher: Surabaya.

M. Marwan dan Jimmy P. 2009. Kamus Hukum; Dictionary Of Law Complete Edition. Reality Publisher: Surabaya. 
Philipus M. Hadjon. 2010. Hukum Administrasi dan Good Governance. Jakarta : Universitas Trisakti.

Tim Penyusun Kamus Pusat Bahasa. 2002. Kamus Besar Bahasa Indonesia (KBBI) Edisi Ketiga. Balai Pustaka: Jakarta. 